\title{
TOLERANCE LIMITATION IN FACING RELIGIOUS DIVERSITY BASED ON THE TEACHING OF ISLAM
}

\author{
Muhammad Hifdil Islam \\ Institut Ilmu Keisalaman Zainul Hasan Genggong Probolinggo \\ muhammad.hifdil@gmail.com
}

Naskah Diterima: 02-12-2019 Direvisi: 20-12-2019 Disetujui: 07-02-2020

\begin{abstract}
Diversity in religion becomes a necessity in human life both from group to state level. However, a lack of understanding on tolerance towards these differences can lead to conflict. This article aims to explain how Islam gives great respect to the diversity of religions and teaches followers to be tolerant of other religions. This article also describes how the Qur'an as the main source of teaching in Islam provides a picture of tolerance in the diversity of religions and is supported by the arguments of some Islamic scholars. The writing model in this article is based on a literature review on the thoughts of Muslim scholars in viewing the teachings of tolerance in Islam. In this article, it can be shown that Islam as a rabmatan lil'alamin religion (a blessing for the whole universe), teaches its followers (moslem) to being tolerant in facing religious diversity at the level of social life. And also, Islam recognizes entities of other religions, and allows theirs followers to do and practice their own worship. However, on the other hand, Islam also teaches moslems to be able to maintain their aqeedah and sharia.
\end{abstract}

Keywords: Religious Diversity, Tolerance, Teaching of Islam

\begin{abstract}
Abstrak
Keberagaman dalam beragama menjadi keniscayaan dalam kebidupan manusia baik dari level berkelompok bingga bernegara. Namun, kurangnya pemahaman akan sikeap toleransi terbadap perbedaan tersebut dapat menimbulkan konflik. Artikel ini bertujuan untuk menjelaskan bagaimana Islam memberikan rasa hormat yang besar terhadap keragaman agama dan mengajarkan pengikut untuk bersikap toleran terbadap agama lain. Artikel ini juga mendeskripsikan bagaimana Al-Qur'an sebagai sumber utama pengajaran dalam Islam memberikan gambaran toleransi dalam keberagaman agama dan didukung oleh argumen beberapa para cendikiawan Islam. Model penulisan pada artikel ini berdasarkan pada kajian pustaka pada beberapa pemikiran cendikiawan muslim dalam melihat pengajaran toleransi dalam Islam. Dalam artikel ini, dapat ditunjuk.kan bahwa Islam sebagai agama yang rabmatan lil'alamin (berkah bagi seluruh alam semesta), mengajarkan untuk dapat bersikap toleran terhadap perbedaan keberagamaan dalam tataran kehidupan sosial dan Islam mengakui entitas agama-agama lain, dan memungkinkan pengikutnya untuk melakukan dan mempraktikkan ibadah mereka sendiri. Namun, disisi lain, Islam juga mengajarkan untuk dapat menjaga sisi aqidah dan syari'ah seorang moslem.
\end{abstract}

Kata kunci: Keragaman Agama, Toleransi, Ajaran Islam 


\section{INTRODUCTION}

For some time, Indonesia has always been exposed to the issue of religious diversity. the issue of religious differences seems to still be an effective tool in achieving certain goals as is commonly done in politics. The indictment against religion is difficult to dispute as a trigger for social conflicts as well as a source of violence that occurs, both inter-religious and intrareligious ${ }^{1}$. History records many bloodsheds in the name of religion, the conflicts are the result of no mutual understanding between one another, which should be manifested in tolerance. Religion itslef in relation to the life of a pluralistic society has a positive impact in the form of a unifying force (centripental), and a negative impact in the form of a breaking power (centrifugal). ${ }^{2}$ to make religion a means of unifying diversity, it requires tolerance by followers.

Tolerance in religious differences is tolerance related to the Aqidah (creed) or divinity that he believes. The followers of one religions must be given the freedom to believe and embrace the religion and tye must be respected. ${ }^{3}$ Religious tolerance is the realization of the expression of religious experience in the form of community. ${ }^{4}$ Various studies show that tolerance can be an indicator of religious harmony. and tolerance is still a problem for the Indonesian people. The level of tolerance in various regions also varies, so that the handling of the problem cannot be uniformed. ${ }^{5}$ The existence of tolerance between religious communities is very important, because the existence of tolerance can create harmony between religions. Tolerance is the beginning of harmony, without tolerance there cannot be mutual respect, love, love and mutual cooperation between religious communities. ${ }^{6}$ But

\footnotetext{
${ }^{1}$ Abdullahi Ahmed An-Na im, "Critical Reflections on Torture, Religion and Politics: Critical Reflections on Torture, Religion and Politics," The Muslim World 103, no. 2 (April 2013): 259-66, https://doi.org/10.1111/muwo.12004; Abdul Chalik, "Religion and Local Politics: Exploring the Subcultures and the Political Participation of East Java Nu Elites in the Post-New Order Era," Journal of Indonesian Islam 4, no. 1 (1 Juni 2010): 109-50, https://doi.org/10.15642/JIIS.2010.4.1.109-150; Arthur Saniotis, "Understanding Mind/Body Medicine from Muslim Religious Practices of Salat and Dhikr," Journal of Religion and Health 57, no. 3 (1 Juni 2018): 849-57, https://doi.org/10.1007/s10943-014-9992-2.

${ }^{2}$ M. Munandar Soelaiman, Ilmu sosial dasar: teori dan konsep ilmu sosial (Refika Aditama, 2001), 229.

${ }^{3}$ José Casanova, Public religions in the modern world (Chicago: University of Chicago Press, 1994$), 87$.

${ }^{4}$ Joachim Wach, The Comparative Study of Religions (Columbia University Press, 1961), 121-32.

${ }^{5}$ Rina Hermawati, Caroline Paskarina, dan Nunung Runiawati, “Toleransi Antar Umat Beragama di Kota Bandung," Indonesian Journal of Anthropology 1, no. 2 (23 Maret 2017): 107, https://doi.org/10.24198/umbara.v1i2.10341; Sabil Mokodenseho dan Ismail Suardi Wekke, "Toleransi Beragama dan Pembelajaran Agama Islam," Prosiding 1, no. 1 (2017): 67-75; Puspo Nugroho, "Internalization of Tolerance Values in Islamic Education," Nadwa 12, no. 2 (7 Januari 2019): 197-228, https://doi.org/10.21580/nw.2018.12.2.2397.

${ }^{6}$ Muhammad Najib Azca, Hakimul Ikhwan, dan Mohammad Zaki Arrobi, "A Tale of Two Royal Cities: The Narratives of Islamists' Intolerance in Yogyakarta and Solo," Al-Jami'ah: Journal of Islamic Studies 57, no. 1 (7
} 
nowadays tolerance is often misinterpreted by acknowledging the truth of all religions. ${ }^{7}$

In Islam, tolerance originates commonly referred to as tasamuh, as-samahah which illustrates the attitude of mutual respect and cooperation among different groups of people both ethnically, linguistically, culturally, politically, and religiously. Therefore, tolerance, is a great and noble concept that is fully an organic part of the teachings of religions, including Islam. ${ }^{8}$ Therefore, Islam has own perspective to implement the tolerance in facing religious diversity.

\section{RESULTS AND DISCUSSION DEFINING RELIGIOUS DIVERSITY}

The term of diversity has meaning awareness of a difference, and this term still has correlation with the term of multicultural. According to Tim Libreeti in Christopher Schroeder said that the term of "multiculturalism" or "diversity" recycle the same rhetorical platitudes that urge people to "celebrate the differences," that vacuously assert that the differences are people's strengths. ${ }^{9}$

Furthermore, in Crushner K. and P. Safford, Carl A Grant and Joan Thrower Timm in the Encyclopedia of Multicultural Education written by Bruce Mitchell and Robert E. Salsabury argue that diversity is a term that refers to the differences in human beings, has been used by multicultural education writers in referring to the great number of different racial, ethnic, and religious groups in the United States. Moreover ${ }^{10}$, the term has been used in referring to individuals whose ethnic heritage originates in another country or who may have

Mei 2019): 25-50, https://doi.org/10.14421/ajis.2019.571.25-50; Jacob Neusner dan Bruce Chilton, ed., Religious tolerance in world religions (West Conshohocken, Pa: Templeton Foundation Press, 2008).

${ }^{7}$ M. Wahid Nur Tualeka, "Kajian Kritis Tentang Toleransi Beragama Dalam Islam," Al-Hikmah 2, no. 2 (15 Desember 2017): 2, http://journal.um-surabaya.ac.id/index.php/Ah/article/view/1104; Alexander R. Arifianto, "Practicing What It Preaches? Understanding the Contradictions between Pluralist Theology and Religious Intolerance within Indonesia's Nahdlatul Ulama," Al-Jami'ab: Journal of Islamic Studies 55, no. 2 (15 Desember 2017): 241-64, https://doi.org/10.14421/ajis.2017.552.241-264; _ Iwan, "Internalisasi Nilai-Nilai Toleransi Dalam Upaya Membina Kerukunan Umat Beragama Di Sekolah: Studi Deskriptif Analitis Di Sman 1 Kuningan” (phd, Universitas Pendidikan Indonesia, 2017), http://repository.upi.edu/28892/10/D_PU_0908657_Appendix.pdf.

8 Dirga Maulana, "The Exclusivism of Religion Teachers: Intolerance and Radicalism in Indonesian Public Schools," Studia Islamika 24, no. 2 (31 Agustus 2017): 395-401, https://doi.org/10.15408/sdi.v24i2.5707; Muhammad Hifdil Islam, "Tolerance in Persepective of Qur'an and Bibel (Comparative Analysis of Religious Tolerance in Diverses Community)," Humanistika 3, no. 2 (1 Juni 2017): 45-58.

${ }^{9}$ Christopher Schroeder, Diverse by Design: Literacy Education Within Multicultural Institutions (Utah State University Press, 2011), 58.

10 Achmad Asrori, "Contemporary Religious Education Model on the Challenge of Indonesian Multiculturalism," JOURNAL OF INDONESLAN ISLAM 10, no. 2 (1 Desember 2016): 261-84, https://doi.org/10.15642/JIIS.2016.10.2.261-284; James A. Banks dan Cherry A. McGee Banks, ed., Multicultural education: issues and perspectives, 7th ed (Hoboken, N.J: Wiley, 2010). 
special educational and other needs. For a pluralistic society, such as the United States, this term conveys far reaching implications. Diverse student groups can include young persons from the culture of poverty, different ethnic and/or racial backgrounds, and students who have special needs due to problems of gender, class and religion, extreme poverty, drug dependency, and language factors.. ${ }^{11}$ In addition, Ilghiz M. Sinagatullin proposes the dimension of diversity are divided into racial, ethnic, linguistic, cultural, religious, sociopolitical, socioeconomic, educational, sexual and ethnographic. ${ }^{12}$

Religion, in the sociological perspective according to Casram has multiple roles and functions, both constructive and destructive. The point is, the role of religion will constructively make the religious bonds become tighter, often even exceeding the bonds of blood and the relationship nasab. Then because of religion, a community or society will live in unified harmony and unity. Conversely, destructively, religion also has destructive power, destroys unity and can even break the bond of unity. It makes a conflict of religious background difficult to predict the end. ${ }^{13}$

Apart from the above dual functions, any human who lives in the midst of multireligious society will crave a peaceful and harmonious atmosphere. The social life of societies formed on the basis of a multicultural and peaceful spirit of pluralism will be possible if all societies are able to accommodate such diversity, so religious tolerance becomes a necessity in an effort to ensure the social stability of this ideological demand. Social life and religion should not be separated from each other and must be integrated into a single unity.

\section{RELIGIOUS DIVERSITY AND ISLAM}

The Indonesian nation has much diversity, not just the matter of customs or culture of art, language and race, but it also includes religious issues. Although the majority of the population of Indonesia embraced Islam, there are several other religions and beliefs that are also embraced by these inhabitants. Christianity, Catholicism, Hinduism, Buddhism and Confucianism are examples of religions that are also embraced by Indonesians. Every religion must have its own rules in worship. But this difference is not a reason to divide. As one brother in the same homeland, every Indonesian citizen has an obligation to keep the

\footnotetext{
${ }^{11}$ Bruce M. Mitchell, Robert E. Salsbury, dan Robert Salsbury, Encyclopedia of Multicultural Education (Greenwood Publishing Group, 1999), 132.

${ }^{12}$ Ilghiz M. Sinagatullin, Constructing Multicultural Education in a Diverse Society (Scarecrow Press, 2003), 5.

13 Casram Casram, "Membangun Sikap Toleransi Beragama dalam Masyarakat Plural," Wawasan: Jurnal Ilmiah Agama dan Sosial Budaya 1, no. 2 (2016): 187-198.
} 
harmony of religious people in Indonesia so that this country remains a unified nation and reach goal such as a prosperous and social justice. Islam in view of diversity is something that is necessarily and become the reality of human life. Many verses of the Qur'an explains the diversity as sunnatullah. Among the Qur'anic verses in this regard are: QS. Yunus/10:99, QS. Hud/11: 118-119, QS. AnNahl/16: 93, QS. AsySyura/26: 8, QS. Al Hujurat/49: 13.

Islam as the religion of rahmatan lil'alamin (blessing for the whole universe), from the beginning despite having affirmed that the true religion is Islam (Ali Imran / 3: 19 and 85), but in principle and social life, Islam recognizes religious entities, other religions and allow their followers to perform and practice their own worship. Islam never forces anyone to convert to Islam. Because one's faith is acceptable if it is done voluntarily without any coercion. There is no use in the faith of a person born of coercion. For what Islam is forced, whereas the truth and the guidance are very clear to anyone who wants the truth of Islam.

History has perpetuated the leadership of the Prophet and his attitude in treating the plural Medina population. As written in "Medina Charter" (shabifah madinah) among the contents of the charter mentioned the existence of the agreement, that if there is an attack on the city of Madinah or its inhabitants, then all ablu shabifab (involved in the Medina Charter) must defend and help the city of Madinah and its inhabitants regardless of religious differences and race. ${ }^{14} 15$

\section{TEACHING OF ISLAM ON TOLERANCE IN FACING RELIGIOUS DIVERSITY}

Islam is a very tolerant religion. Obviously this is inappropriate if Islam is accused of extremism and radicalism. Especially by saying the Qur'an and Prophet Muhammad as the core of all terror. Islam recognizes diversity existence, including diversity in religion. In Islam, a Muslim is forbidden to force others to abandon their religion and convert to Islam by compulsion, because Allah has said:

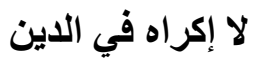

"There is no compulsion to (enter) religion (Islam)." (Surat Al-Baqarab: 250).

\footnotetext{
${ }^{14}$ Ajid Thohir, Perkembangan peradaban di kawasan dunia Islam: melacak akar-akar sejarah, sosial, politik, dan budaya umat Islam (Divisi Buku Perguruan Tinggi, RajaGrafindo Persada, 2004), 283.

${ }^{15}$ Ajid Thohir. 2014. Sirah Nabawiyah. Bandung: Penerbit Marja. Pg. 283
} 
If we look back at the history of Islam, we will see and realize that there is not found about the death penalty or torture on someone who does not want to convert to Islam. The real example is we can see how the spread of Islam by the Wali Songo in Indonesia.

All humans will not be able to reject this sunnatullah. Thus, for man, it is appropriate to follow God's guidance in the face of those differences. Religious tolerance does not mean that we today can be free to adopt a particular religion and tomorrow we follow other religions or freely follow the rituals and rituals of all religions without the existence of binding rules. However, religious tolerance should be understood as a form of our acknowledgment of the existence of religions other than our religion by all forms of system, and the manner of worship and giving freedom to practice their respective religious beliefs. The principle of freedom of determining and choosing this religion is increasingly clear and firmly put forward by the Qur'an in Surah Al-Baqarah verse $256^{16}$ :

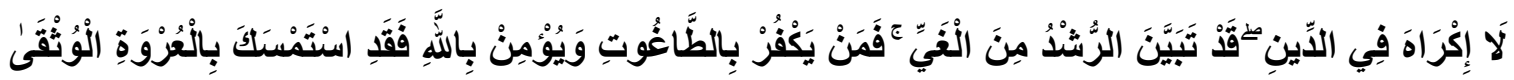

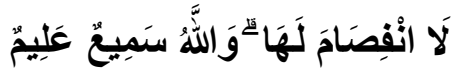

"There is no compulsion to embrace religion (Islam). Indeed, the path is clearer than the perverse path. Therefore, whoever disbelieves in Thaghut and believes in Allah, then surely be has clung to a strong rope that will never break. Allah is the Hearer, the Knower"

Ibnu Katsir has an opinion that there is no compulsion in religion (Islam). Allah Almighty does not compel a person to enter and believe in the religion of Islam, so Allah swt strictly forbids a person to force let alone rebuke another with the intention that they enter the religion Islam. Because actually the arguments and evidence of truth has been shown by Allah SWT clearly and gambling, so there is no need for coercion on someone to embrace it. ${ }^{17}$

Also, in the days of the Shababat, followers of religion other than Islam is given the opportunity to perform freely and safely religious freedoms by obtaining guarantees of the law. ${ }^{18}$ In addition, Islam even forbade his people to insult other religious rituals (QS Al-An`am

${ }^{16}$ Al-Qur`an (Jakarta: Kementerian Agama RI, 2010), 2-256.

${ }^{17}$ Damasqy Ismail bin Umar, Tafsir Ibnu Katsir, 3 ed., vol. 1, 4 vol. (Beirut Lebanon: Dar al-Kotob AlIlmiyah, 2010).

${ }^{18}$ Nur Achmad, Pluralitas agama: kerukunan dalam keragaman (Kompas Media Nusantara, 2001); Yusuf alQaradhawi, "Priorities of the Islamic movement in the Coming Phase," Swansea: Awakening Publications, 2000, 
/ 6: 108).

In the teachings of Islam itself, according to Muhammad Yasir, tolerance is part of the vision of Islamic theology or aqidah and entered into the system of Islamic theology. This should be studied in depth and applied in all aspects of religious life, because it is a social necessity for all people who already have full trust in him as a creature of God who has complete faith. ${ }^{19}$ The ideal religious tolerance should be established by the active participation of all members of the religious community living in plurality in order to achieve the same goals on the basis of togetherness, respect and mutual understanding of the implementation of certain rituals and doctrines of each religion. Various formulations on the typology of interreligious relationships such as exclusiveness, inclusiveness, pluralism and so on are often put forward to bring this diversity to a more intensive stage of religious harmonious dialogue.

In the book Tafsir Rubul Ma'ani Shihab al-Din al-Sayid Mahmud al-Alusi al-Baghdadi explains the attitude of "loving" human/creature other than himself is one of our love to God. Then humanitarian attitudes become the way for people to get closer to God. Love in the view of Al Alusi is an omnipotent God Almighty given to human beings, none other than to perform the ritual of worship to him. One must make a sacrifice if he really loves God and his Messenger, because he thinks love without sacrifice is just a falsehood, and God does not like falsehood at all. In accordance with the concept of love built by Al Alusi that human relation (Hablum Minan Nas) should be based on love to God. In this case, the priority of love that $\mathrm{Al}$ Alusi builds is love for God. Slightly different from the concept of love that was awakened by Rabi'ah Al Adawiyah that love to man only as a relative of his longing for Allah, while the concept of love built by Al Alusi love to man is iradab (essential) of God, because the basic meaning of love is the union of a person the loving and the loved ones. In short, $\mathrm{Al}$ Alusi gives one concept that love to God does not have to deny love to man, because love to man is part of the power of God to man. And from here the values of multiculturalism are shown. ${ }^{20}$

The concept of tolerance as one of multiculturalism value according to Muhammad Quraish Shihab in al-Mishbah tafsir is an understanding where one recognizes the diversity and difference as sunnatullah. God's declaration of diversity has the purpose of getting people

http://is.muni.cz/el/1421/podzim2013/RLB379/um/45655867/45656045/Yusof_Al-Qardhawi_-_s.72_-83.pdf.

${ }^{19}$ Muhammad Yasir, "Makna Toleransi Dalam Al-Qur'an," Jurnal Ushuluddin 22, no. 2 (1 Desember 2014): 170-80, https://doi.org/10.24014/jush.v22i2.734.

${ }^{20}$ Abu al Sana Shihab al Din al Sayyid Mahmud Al Alusi, Rub al Ma" ani Fi Tafsir al Qur" an al Azim wa al Sab" al Masani, vol. 1 (Lebanon: Beirut: Dar al Kutub al 'Ilmiyah, 1994), 4-5. 
to know each other (Q.S al-Hujurat: 13), to help each other (Q.S al-Maidah: 2), and always to vie for good (Q.S al-Maidah: 48). Diversity is what will lead people to achieve the common good. Responding to diversity does not mean confusing various cultures / religions into oneon-one, but to live in mutual respect, respect, understanding and tolerance is the most appropriate solution to create a safe, peaceful and harmonious life. ${ }^{21}$ Then, one form of religious radicalism is rebellion or in Islam called the term al-baghy. According to Abd. AlQadir Audah in the perspective of Islamic law, the behavior will lead to extreme through violence in order to maintain its ideology can be regarded as al-baghy (rebel). In Islamic law, rebels fall into the category of crime (jarimah) which may be subject to capital punishment. ${ }^{22}$

In addition, in the Tafsîr Al-Rä̌r (tafsir Mafatibul Ghaib / Al-Kabir) composed by Imām Fakhruddîn Ar-Razî contains many multicultural values, this is evidenced by the making of Tafsir $A r-R \bar{a} \ddot{\imath}$ as a reference from various groups. But of the multicultural values present in the Tafsîr $A r-R \bar{a} z \hat{\imath}$, there are three values that need to be given more attention, because these three values are considered to be representative of the multicultural values taught by Imam Fakhruddîn Ar-Razî. In addition, these three values also work directly on the learning done in the classroom. These values are: (1). Learn to live in difference; (2). Freedom of opinion or openness in thinking, (3). Mutual respect. The valuesof tolerance education according to Muhammad Fakhr al-Din al-Razi such as First, The value of religious education, namely the faith as a single truth principle in religion. In Tafsir al-Kabir, Al Razi does not justify a religious attitude that equates the truth of all religions or many religions. Attitudes like this can lead to internal and external conflicts of religion. In religious relations, the interpretation of Surah alKafirun is very appropriate to reinforce religious beliefs when many things appear to make faith fade. This value strictly prohibits that it is not permissible for Muslims to compromise in the affairs of worship (aqidah and shari'ab). It is not justified for Muslims to follow the process of worship or alternate ways of worship with other people. This value serves as a suppression so that Muslims are not trapped to Syncretism or homogenism of religion. Second, the value of religious tolerance education, which contains the freedom to choose religious choice: Muslims in Indonesia currently occupy positions as majority group. Yet it is not permissible for Muslims to influence by showing superiority so that followers of other religions follow their will. It is better to give up people other than Islam to keep their faith and practice their religion. Because basically to follow Islam is actually on the guidance of Allah SWT. The value

\footnotetext{
${ }^{21}$ Moh Quraish Shihab, Tafsir Al-Misbah (Jakarta: Lentera Hati, 2005), 615-16.

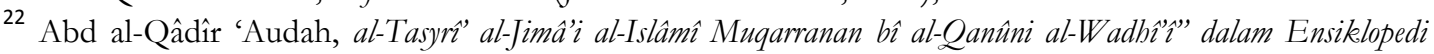
Hukum Islam (Bogor: Kharisma Ilmu, 2010), 111.
} 
of tolerance education here is to give freedom to non-Muslims of their desire to embrace the religion of their choice, then recognize it as a plurality of life. Muslims give an agreement to non-Muslims to freely express the attitude of worship according to their respective religions. Then maintain their security in carrying out religious teachings without the need to feel fear or fear of threats or discrimination from the outside. The value of religious harmony from the interpretation of Surab al-Kafirun is; The plurality of religions as reality becomes a valuable resource in building harmony. Indonesia has a golden opportunity because this distinction will produce a variant product ${ }^{23}$. This requires tolerance as a large bridge that unifies the various poles of horizontal difference. The value of this harmony can be implemented from religious dialogue to solve every religious horizontal issue. Religious dialogue becomes important as education to understand the existence and respect of other entities. ${ }^{24}$

Last, Yusuf Qordlawi points out some prominent principles in teaching. Islamic values that must be adaptive to diversity and plurality, including: ${ }^{25}$

- Education is done to liberate people from worship to humans. This principle according to Qardhawi as a pure monotheistic principle. Islamic education and da'wah in this case must free human beings from servitude to their fellowmen, as well as the servitude of objects that are illusory or the essence of things.

- Education to foster the bonding of brotherhood and human equality. According to Qardhawi brotherhood is the fruit of taubid which is sentenced by Islam and its consequence is human equality. The brotherhood was built in several ways including: First the human position as a servant of God who has created them is equal before Him. Second; as the son of Adam, although different skins, colors, customs and cultures in essence there is no difference between them is equally from Adam. This is in accordance with what was conveyed by Prophet Muhammad SAW at the time of his pilgrimage (Haji Wada) that there is no difference between Arab and not Arab, only their faith that able distinguish them.

- Education for the justice of all mankind. Among Qardhawi's call for the good of

\footnotetext{
${ }^{23}$ Muhammad Anas Ma `arif, "Internalisasi Nilai Multikulutural Dalam Mengembangkan Sikap Toleransi ( Studi Di Di Pesantren Mahasiswa Universitas Islam Malang)," Nazhruna: Jurnal Pendidikan Islam 2, no. 1 (24 Maret 2019), https://doi.org/10.31538/nzh.v2i1.179; Hamlan Andi Baso Malla, "Pembelajaran Pendidikan Agama Islam Berbasis Multikultural Humanistik Dalam Membentuk Budaya Toleransi Peserta Didik Di SMA Negeri Model Madani Palu, Sulawesi Tengah," INFERENSI: Jurnal Penelitian Sosial Keagamaan 11, no. 1 (1 Juni 2017): 163-86, https://doi.org/10.18326/infsl3.v11i1.163-186.

${ }^{24}$ FUAD HASAN, "Nilai-nilai pendidikan toleransi dalam sūrah al-kāfirūn" (Thesis, Jogjakarta, UIN Sunan Kalijaga, 2014), 101-3.

${ }^{25}$ Yusuf Qaradawi, Sistem pendidikan ikhwanul muslimin (Media Da’wah, 1983), 63.
} 
mankind is to uphold justice between fellow human beings. Justice is not for Arabs only, Islamic justice is syumul (comprehensive). Education for World Peace. As a peace-loving religion, world peace is a part of Islamic education.

Islam considers that the plurality of religions, beliefs, and cultures is not a threat or a basic cause of conflict. Islam also does not see that the claims of truth (truth claims) of each religion as a trigger of the emergence of war and conflict. Therefore, Islam does not wish to abolish the truth claim of each religion or belief; or trying to uniform "certain views" on each religion, as did pluralist groups.

In other words, Islamic solutions to cultural diversity, religion, and beliefs are not by eliminating truth claims, or destroying the identity of religions other than Islam. However, Islam recognizes the existence of diversity, and provides protection of the diversity. Therefore, Islam does not accept the idea of pluralism that wants to eliminate truth claims, or who wish to dilute the identity of religions other than Islam. In the view of Islam, Jews are not forced or persuaded to believe in a view that all religions are equally true; or to believe that all religions worship the same God even in different ways (perennial philosophy). Islam also does not impose or peddle the idea that all religions must abandon their own religious identity and flock to a universal religion. Islam does not want the Jews and Christians to abandon their religious identity, and be persuaded to embrace a universal religion like the pluralist's advice. Islam also allows other believers to believe in the truth of their religion and beliefs. Islam also does not want to abolish their truth claims. Islam only invites them to enter into Islam. If they refuse, they are allowed to remain in their religion and belief.

\section{CONCLUSION}

Religious diversity is sunnatullah, something that is given. As well as diversity in language, likes and culture. Therefore any attempt to confront a religious entity is a futile effort and the same as against the provisions of God. As against the provisions of God about the diversity of character, tribe, language and culture. This has been clearly described in the Qur'an. The attitude that must be built in addressing the reality of religious diversity is to improve the correct tolerant attitude, mutual respect and respect with full maturity attitude in religion. As well as enhance cooperation in things that become common goals in religion, without having to suspect each other. Besides the need to strengthen the three pillars of statehood (Pancasila, UUD 45 and Binneka Tunggal Ika). So, it can be concluded the Islam recognizes and accommodates diversity especially in religious diversity, and does not eliminate 
truth claims and the identity of non-Islamic religions, but it can accepts the existence the religious diversity. Then, Islam totally rejects the idea of pluralism that wants to lead all religions to abolish its own truth claims; or to dilute the identity of their respective religion. The religious diversity itself cannot be abandoned the individual. Building tolerance among religious diversity culture should be begun from individual. It is because individual will form a micro culture (his or her community) and it will affect the macro culture (Indonesia). However, being tolerance in religious diversity does not have recognize or admit the whole truth in other religion. Still, an exclusivity in religion such as aqidah and syariah must be maintained by the follower. The inclusivity of religion will be applied in social and justice area.

\section{REFERENCE}

Abd al-Qâdîr 'Audah. al-Tasyrî' al-Jimâ'i al-Islamî Muqarranan bî al-Qanûni al-Wadhî̀'̂̀' dalam Ensik:lopedi Hukum Islam. Bogor: Kharisma Ilmu, 2010.

Abu al Sana Shihab al Din al Sayyid Mahmud Al Alusi. Ruh al Ma"ani Fi Tafsir al Qur" an al Azim wa al Sab" al Masani,. Vol. 1. Lebanon: Beirut: Dar al Kutub al 'Ilmiyah, 1994.

Achmad, Nur. Pluralitas agama: kerukunan dalam keragaman. Kompas Media Nusantara, 2001.

Al-Qur`an. Jakarta: Kementerian Agama RI, 2010.

An-Na im, Abdullahi Ahmed. "Critical Reflections on Torture, Religion and Politics: Critical Reflections on Torture, Religion and Politics." The Muslim World 103, no. 2 (April 2013): 259-66. https://doi.org/10.1111/muwo.12004.

Arifianto, Alexander R. "Practicing What It Preaches? Understanding the Contradictions between Pluralist Theology and Religious Intolerance within Indonesia's Nahdlatul Ulama." Al-Jami'ab: Journal of Islamic Studies 55, no. 2 (15 Desember 2017): 241-64. https://doi.org/10.14421/ajis.2017.552.241-264.

Asrori, Achmad. "Contemporary Religious Education Model on the Challenge of Indonesian Multiculturalism.” JOURNAL OF INDONESLAN ISLAM 10, no. 2 (1 Desember 2016): 261-84. https://doi.org/10.15642/JIIS.2016.10.2.261-284.

Azca, Muhammad Najib, Hakimul Ikhwan, dan Mohammad Zaki Arrobi. "A Tale of Two Royal Cities: The Narratives of Islamists' Intolerance in Yogyakarta and Solo.” AlJami'ab: Journal of Islamic Studies 57, no. 1 (7 Mei 2019): 25-50. https://doi.org/10.14421/ajis.2019.571.25-50. 
Banks, James A., dan Cherry A. McGee Banks, ed. Multicultural education: issues and perspectives. 7th ed. Hoboken, N.J: Wiley, 2010.

Casanova, José. Public religions in the modern world. Chicago: University of Chicago Press, 1994.

Casram, Casram. "Membangun Sikap Toleransi Beragama dalam Masyarakat Plural.” Wawasan: Jurnal Ilmiah Agama dan Sosial Budaya 1, no. 2 (2016): 187-198.

Chalik, Abdul. "Religion and Local Politics: Exploring the Subcultures and the Political Participation of East Java Nu Elites in the Post-New Order Era." Journal of Indonesian Islam 4, no. 1 (1 Juni 2010): 109-50. https://doi.org/10.15642/JIIS.2010.4.1.109-150.

HASAN, FUAD. "Nilai-nilai pendidikan toleransi dalam sūrah al-kāfirūn." Thesis, UIN Sunan Kalijaga, 2014.

Hermawati, Rina, Caroline Paskarina, dan Nunung Runiawati. "Toleransi Antar Umat Beragama di Kota Bandung." Indonesian Journal of Anthropology 1, no. 2 (23 Maret 2017). https://doi.org/10.24198/umbara.v1i2.10341.

Islam, Muhammad Hifdil. "Tolerance in Persepective of Qur'an and Bibel (Comparative Analysis of Religious Tolerance in Diverses Community)." Humanistika 3, no. 2 (1 Juni 2017): 45-58.

Ismail bin Umar, Damasqy. Tafsir Ibnu Katsir. 3 ed. Vol. 1. 4 vol. Beirut Lebanon: Dar alKotob Al-Ilmiyah, 2010.

Iwan, _. "Internalisasi Nilai-Nilai Toleransi Dalam Upaya Membina Kerukunan Umat Beragama Di Sekolah: Studi Deskriptif Analitis Di Sman 1 Kuningan.” Phd, $\begin{array}{lll}\text { Universitas Pendidikan Indonesia, } & 2017 .\end{array}$ http://repository.upi.edu/28892/10/D_PU_0908657_Appendix.pdf.

Ma`arif, Muhammad Anas. "Internalisasi Nilai Multikulutural Dalam Mengembangkan Sikap Toleransi ( Studi Di Di Pesantren Mahasiswa Universitas Islam Malang).” Ną̧runa: Jurnal Pendidikan Islam 2, no. 1 (24 Maret 2019). https://doi.org/10.31538/nzh.v2i1.179.

Malla, Hamlan Andi Baso. "Pembelajaran Pendidikan Agama Islam Berbasis Multikultural Humanistik Dalam Membentuk Budaya Toleransi Peserta Didik Di SMA Negeri Model Madani Palu, Sulawesi Tengah.” INFERENSI: Jurnal Penelitian Sosial Keagamaan 11, no. 1 (1 Juni 2017): 163-86. https://doi.org/10.18326/infsl3.v11i1.163-186.

Maulana, Dirga. "The Exclusivism of Religion Teachers: Intolerance and Radicalism in Indonesian Public Schools." Studia Islamika 24, no. 2 (31 Agustus 2017): 395-401. https://doi.org/10.15408/sdi.v24i2.5707. 
Mitchell, Bruce M., Robert E. Salsbury, dan Robert Salsbury. Encyclopedia of Multicultural Education. Greenwood Publishing Group, 1999.

Mokodenseho, Sabil, dan Ismail Suardi Wekke. "Toleransi Beragama dan Pembelajaran Agama Islam.” Prosiding 1, no. 1 (2017): 67-75.

Neusner, Jacob, dan Bruce Chilton, ed. Religious tolerance in world religions. West Conshohocken, Pa: Templeton Foundation Press, 2008.

Nugroho, Puspo. “Internalization of Tolerance Values in Islamic Education.” Nadwa 12, no. 2 (7 Januari 2019): 197-228. https://doi.org/10.21580/nw.2018.12.2.2397.

Qaradawi, Yusuf. Sistem pendidikan ikhwanul muslimin. Media Da’wah, 1983.

Qaradhawi, Yusuf al-. "Priorities of the Islamic movement in the Coming Phase." Swansea: Awakening Publications, 2000. http://is.muni.cz/el/1421/podzim2013/RLB379/um/45655867/45656045/Yusof_ Al-Qardhawi_-_s.72_-_83.pdf.

Saniotis, Arthur. "Understanding Mind/Body Medicine from Muslim Religious Practices of Salat and Dhikr." Journal of Religion and Health 57, no. 3 (1 Juni 2018): 849-57. https://doi.org/10.1007/s10943-014-9992-2.

Schroeder, Christopher. Diverse by Design: Literacy Education Within Multicultural Institutions. Utah State University Press, 2011.

Shihab, Moh Quraish. Tafsir Al-Misbah. Jakarta: Lentera Hati, 2005.

Sinagatullin, Ilghiz M. Constructing Multicultural Education in a Diverse Society. Scarecrow Press, 2003.

Soelaiman, M. Munandar. Ilmu sosial dasar: teori dan konsep ilmu sosial. Refika Aditama, 2001.

Thohir, Ajid. Perkembangan peradaban di kawasan dunia Islam: melacak akar-akar sejarah, sosial, politik, dan budaya umat Islam. Divisi Buku Perguruan Tinggi, RajaGrafindo Persada, 2004.

Tualeka, M. Wahid Nur. "Kajian Kritis Tentang Toleransi Beragama Dalam Islam.” AlHikmah 2, no. 2 (15 Desember 2017). http://journal.umsurabaya.ac.id/index.php/Ah/article/view/1104.

Wach, Joachim. The Comparative Study of Religions. Columbia University Press, 1961.

Yasir, Muhammad. "Makna Toleransi Dalam Al-Qur'an.” Jurnal Ushuluddin 22, no. 2 (1 Desember 2014): 170-80. https://doi.org/10.24014/jush.v22i2.734. 